\title{
PENERAPAN METODE MONTE CARLO UNTUK SIMULASI SISTEM ANTRIAN SERVICE SEPEDA MOTOR BERBASIS WEB
}

\author{
Siti Aminatunnisa, Diarnia Mega Selfia Sembiring, Yeni Gultom, Enjelika Matondang, Mazmur Saleh Pasaribu, \\ Evta Indra* \\ Program Studi Sistem Informasi Fakultas Teknologi dan Ilmu Komputer, Universitas Prima Indonesia \\ E-mail : *evtaindra@unprimdn.ac.id
}

\begin{abstract}
ABSTRAK- Antrian merupakan suatu kegiatan dimana beberapa orang berbaris atau menunggu pada suatu fasilitas pelayanan kemudian dilayani, dan akhirnya meninggalkan fasilitas tersebut setelah dilayani untuk memenuhi sesuatu yang mereka inginkan. Antrian terjadi apabila waktu proses lebih besar dari pada waktu antar kedatangan. Simulasi sistem antrian adalah sistem informasi berbasis komputer yang digunakan untuk merancang model suatu sistem antrian secara nyata guna memahami tingkah laku sistem tersebut. Secara umum, sistem antrian servis pada bengkel-bengkel masih dilakukan secara konvensional, sehingga banyaknya konsumen serta jadwal perbaikan sepeda motor mengalami keterlambatan perbaikan. Untuk mengatasi masalah tersebut dalam penelitian ini akan dibangun aplikasi simulasi sistem antrian servis menggunakan metode Monte Carlo berbasis Web yang diharapkan dapat meningkatkan kinerja pelayanan, dan mengurangi waktu tunggu konsumen sehingga pelayanan yang diberikan petugas kepada konsumen akan memberikan kepuasan tersendiri. Berdasarkan hasil penelitian terdapat perbedaan yang signifikan sebelum dan sesudah menggunakan sistem. Kata kunci: Antrian, Monte Carlo dan Simulasi
\end{abstract}

\section{PENDAHULUAN}

Perkembangan teknologi informasi saat ini tidak lepas dari pesatnya perkembangan teknologi komputer, karena komputer merupakan media yang dapat memberikan kemudahan bagi manusia dalam menyelesaikan suatu pekerjaan. Hal ini tidak terlepas dari aktivitas manusia yang kerap kali ditunjang dengan teknologi informasi itu sendiri yang mampu menjawab tuntutan pekerjaan yang lebih mudah dan menghemat waktu. Teknologi informasi sangat membantu bagi perusahaan atau instansi dalam mengolah data-data pekerjaan sehingga mendapatkan suatu informasi yang akurat. Simulasi sistem antrian adalah sistem informasi berbasis komputer yang digunakan untuk merancang model suatu sistem antrian secara nyata guna memahami tingkah laku sistem tersebut[1].

Dalam beberapa tahun terakhir, penelitian yang berhubungan dengan simulasi sistem antrian semakin banyak dilakukan[1], Banyaknya penelitiaaan tersebut, disebabkan oleh meningkatnya kebutuhan untuk mengatasi keterbatasan sistem antrian konvensional yang masih banyak digunakan dibengkel-bengkel.

Secara umum, sistem antrian servis pada bengkel-bengkel masih dilakukan secara konvensional (sehingga memungkinkan terjadinya ketidaknyamanan para pelanggan karena antrian yang panjang). Untuk mengatasi masalah tersebut dalam penelitian ini akan dibangun aplikasi simulasi sistem antrian servis menggunakan metode Monte Carlo[2]. Berdasarkan hasil penelitian terdapat perbedaan yang signifikan sebelum dan sesudah menggunakan sistem.

\section{ISI PENELITIAN}

\subsection{Sistem}

Dalam kehidupan sehari-hari di era teknologi dan komputerisasi saat ini, kita sering mendengar istilah mengenai sistem. Misalkan sistem komputer, sistem operasi, sistem informasi, sistem geografis, sistem akademis, dan lainnya. Bahkan disadari maupun tidak, kita sering menggunakan ataupun memanfaatkan layanan yang diberikan oleh sistem tersebut. Kita juga terbantu dengan adanya sistem tersebut. Kemudian muncul sebuah pertanyaan apakah yang dimaksud dengan sistem?

Sstem didefinisikan sebagai suatu kumpulan objek yang saling berkaitan dan saling bergantung secara tetap untuk mencapai tujuan bersama dalam suatu lingkungan yang kompleks[3]. Banyak sistem yang dipelajari atau dijumpai dalam kehidupan sehari-hari seperti sistem tata surya, sistem informasi, sistem komunikasi, sistem antrian, dan lain-lain. Di dalam setiap sistem tersebut terdapat entitas yang saling berinteraksi. Sebagai contoh, dalam antrian sebuah bank terdapat sejumlah nasabah yang masuk ke dalam sistem dan terdapat sejumlah teller yang melayani nasabah. Dalam sistem antrian bank terdapat juga aturan-aturan yang 
harus dipatuhi oleh nasabah seperti pemisahan pelayanan nasabah berdasarkan nominal uang yang akan ditransaksikan. Entitas-entitas dan aturan dalam sistemberinteraksi sehingga menghasilkan sistem antrian yang sedemikian rupa.

\subsection{Antrian}

Antrian adalah orang-orang atau barang dalam barisan yang sedang menunggu untuk dilayani. Di dalam sistem antrian terdapat komponen yang sangat penting untuk menentukan peraturan dari sistem pelayanan untuk membuat pelayanan menjadi tertib dan teratur[4].

Antrian dalam arti kedatangan pelanggan untuk mendapatkan pelayanan, menunggu untuk dilayani jika fasilitas pelayanan(server) masih sibuk, mendapatkan pelayanan dan kemudian meninggalkan sistem setelah dilayani[5].

Dalam pendapat lain antrian ialah suatu garis tunggu dari nasabah (satuan) yangmemerlukan layanan dari satu atau lebih pelayan (fasilitas layanan). Pada umumnya, sistema ntrian dapat diklasifikasikan menjadi sistem yang berbeda - beda di mana teori antrian dan simulasi sering diterapkan secara luas[6].

Beberapa klasifikasi sistem antrian adalah sebagai berikut:

1. Sistem pelayanan komersial merupakan aplikasi yang sangat luas dari model -model antrian,seperti restoran, kafetaria, toko-toko, salon, butik, supermarket, dan sebagainya.

2. Sistem pelayanan bisnis - industri Sistem pelayanan bisnis - industri mencakup lini produksi, sistem material - handling, sistempergudangan, dan sistem - sistem informasi komputer.

3. Sistem pelayanan transportasi

4. Sistem pelayanan sosial

Sistem pelayanan sosial merupakansistem sistem pelayanan yang dikelola oleh kantor kantor dan jawatan - jawatan lokal maupun nasional, seperti kantor registrasi SIM dan STNK, kantor pos, rumah sakit,puskesmas, dan lain - lain.

Antrian merupakan suatu kondisi dimana adanya objek yang akan dilayani tetapi keterlambatan disebabkan oleh mekanisme pelayanan mengalami kesibukan.Antrian terjadi karena adanya ketidakseimbangan antara ketersediaan dengan kebutuhan yang harus dipenuhi untuk melayani. Antrian juga sering terjadi karena perbedaan waktu antar kedatangan dan layanan yang berbeda. Bentuk dari suatu antrian dapat dilihat pada Gambar 1

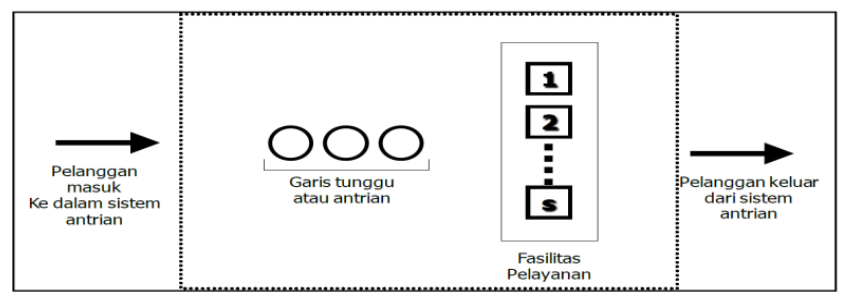

Gambar 1. Bentuk Sistem Antrian

\section{Disiplin Antrian}

Disiplin antrian adalah aturan yang mengatur pelayanan kepada para pelanggan sejak pelanggan itu datang sampai pelanggan itu meninggalkan tempat pelayanan. Aturan menurut kedatangan didasarkan pada:

FIFO (First In First Out) yaitu pelayanan menurut urutan kedatangan atau pelanggan yang pertama

1. datang pertama keluar. Contohnya pada antrian di loket-loket penjuan karcis kereta api.

2. LIFO (Last In FirstOut) yaitu pelanggan yang terakhir datang yang mendapatkan pelayanan yang pertama atau pelanggan yang terakhir datang yang pertama keluar. Contohnya pada sistem bongkar muat barang di dalam truk, dimana barang yang masuk terakhir justru akan keluar terlebih dahulu.

3. SIRO (Service In Random Order) yaitu pelayanan dalam urutan acak. Contohnya pada arisan, dimana pelayanan dilakukan secara undian.

4. PRI (Priority service) yaitu urutan prioritas maksudnya pelayanan dilakukan berdasarkan urutan prioritas. Contohnya dalam suatu pesta atau acara dimana tamutamu yang dikategorikan VIP akan dilayani terlebih dahulu.

\subsection{Model}

Model adalah pendekatan atau abstraksi dari suatu sistem yang dikembangkan untuk tujuan studi. Model berisikan hal-hal (variabel) yang relevan dengan sistem nyata yang ada. Observasi dalam sebuah sistem dapat menjadi dasar dalam pembentukan sebuah model. Model terdiri atas model analog dan model simbolik. Untuk model analog, pemodelan sistem nyata dilakukan melalui tingkah laku, sedangkan model simbolik berasaskan pada perspektif, verbal, matematik dan logika berpikir dari pemodel[7]. 
Model merupakan suatu deskripsi atau analogi yang digunakan untuk membantu menggambarkan sesuatu yang tdak dapat dinamai secara langsung. Pada umumnya model didefinisikan sebagai suatu representasi sistem nyata. Sistem nyata adalah sistem yang sedang berlangsung di dunia nyata dan menjadi titik permasalahan yang sedang diteliti. Model dapat diklasifikasikan menjadi model ikonik, analog dan simbolik.

1. Model ikonik adalah mempresentasikan suatu sistem atau benda menjadi suatu objek model yang wujudnya menyerupai sistem tersebut.

2. Model analog adalah model yang mampu mempresentasikan sifat suatu sistem menjadi lebih sederhana.

3. Model simbolik atau model matematis adalah representasi secara abstrak dari suatu sistem.

\subsubsection{Struktur Dasar Model Antrian}

Proses antrian pada umumnyadikelompokan kedalam empat struktur dasar model antrian, menurut sifat-sifat pelayanan dari suatu fasilitas pelayanan yang ada yaitu[8]:

1. Single Channel-Single Phase

Single Channel - Single Phase adalah suatu bentuk antrian yang hanya terdapat satu antrian dan satu pelayanan.

Contohnyadalam hal ini adalah seorang kasir (tuggal),seorang tukang parkir (tunggal), dan sebagainya. Lebih jelasnya dapat dilihat Gambar 2 sebagai berikut:

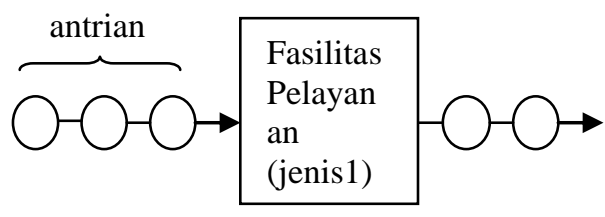

\section{Gambar 2. Single Channel-Single Phase}

\section{Single Channel-Multi Phase}

Single Channel - Multi Phase adalah suatu bentuk antrian yang hanya terdapat satu antrian dan terdapat dua atau lebih pelayanan. Contohnya dalam hal ini adalah pada proses pembuatan surat izin mengemudi, dimana pelanggan yang datang harus mengantri pada beberapa tempat pelayanan dalam satu proses pembuatan surat izin mengemudi. Untuk struktur dari suatu sistem antrian Single Channel- Multi Phase dapat dilihat pada Gambar 3 sebagai berikut:

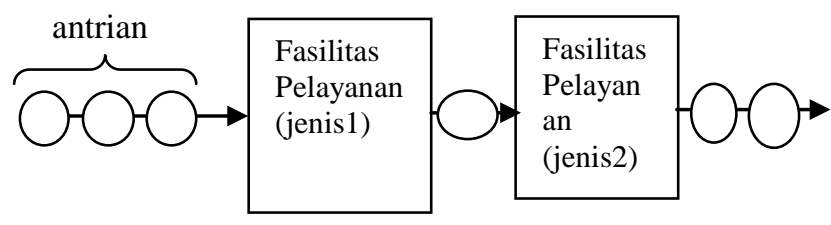

Gambar 3. Single Channel-Multi Phase

3. Multi Channel-Single Phase

Multi Channel - Single Phase adalah suatu bentuk antrian yang memiliki dua atau lebih antrian dan satu pelayan. Contohnya dalam hal ini adalah pelayan pada pembayaran rekening telepon, pelayan pada bank, dan pelayan pada rekening listrik yang terdiri dari beberapa baris antrian dan setiap antrian mempunyai masingmasing satu pelayan. untuk struktur dari sistem antrian Multi Channel-Single Phase dijelaskan lebih rinci pada Gambar 4 sebagai berikut:

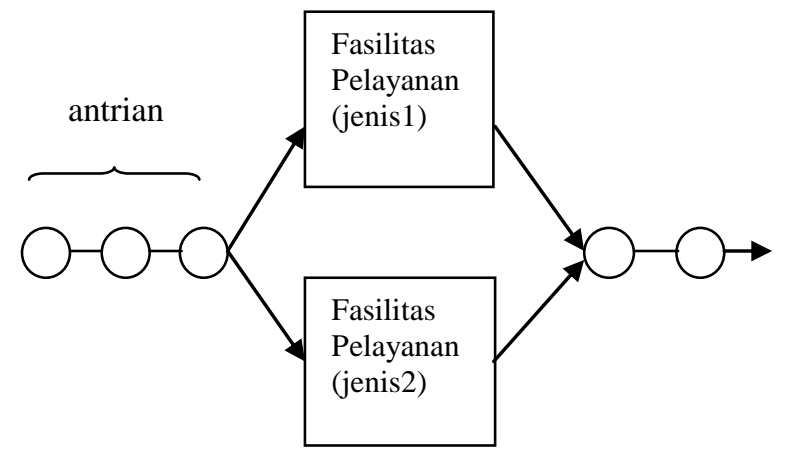

Gambar 4. Multi Channel-Single Phase

4. Multi Channel-Multi Phase

Multi Channel - Multi Phase adalah suatu bentuk antrian yang memiliki dua atau lebih antrian maupun pelayan. Contohnya dalam halini adalah pada pendaftaran siswa baru di SD,SMP, SMA dan sebagainya. Untuk struktur dari sistem antrian Multu Channel - Multi Phaset dapat dilihat pada Gambar 5 sebagai berikut:

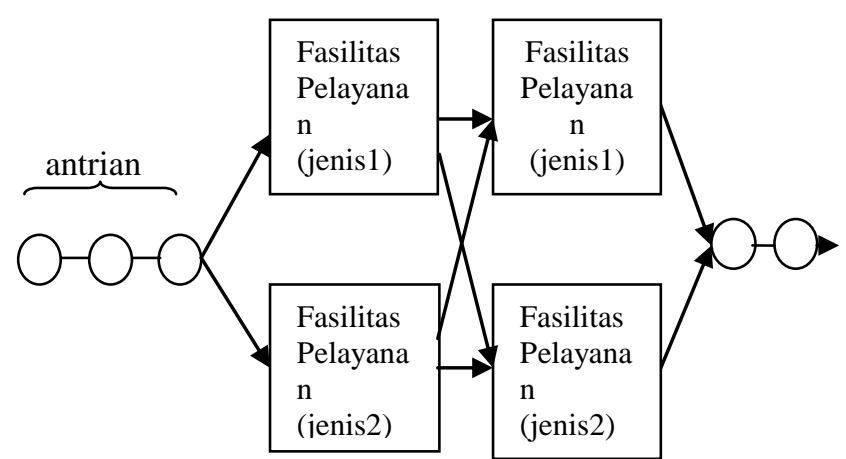

Gambar 5. Multi Channel- Multi Phase

\subsection{Definisi Simulasi}

Simulasi merupakan teknik untuk meniru operasi-operasi atau proses yang terjadi dalam 
sebuah sistem dengan menggunakan bantuan perangkat komputer dan dilandasi oleh beberapa asumsi tertentu sehingga sistem tersebut bisa dipelajari secara ilmiah. Dalam simulasi dijumpai adanya kejadian yang difokuskan untuk menganalisis sebuah sistem. Untuk memprediksi kejadian yang terjadi, dapat dilakukan pendekatan dalam aspek statistik dan probabilitas sebagai data yang diperlukan untuk dilakukannya simulasi.

Tingginya keinginan manusia untuk mendapatkan kualitas yang terbaik, meminimalisasi kehilangan waktu, meminimalisasi biaya, menyebabkan orang mulai berpikir tentang sistem. Simulasi dapat didefinisikan sebagai suatu teknik dalam pembuatan suatu model dari sistem yang nyata atau usulan sistem sedemikian sehingga perilaku dari sistem tersebut pada kondisi tertentu dapat dipelajari. Alasan digunakannya simulasi, diantaranya karena simulasi mengurangi biaya, waktu, dan tenaga serta tidak merusak sistem yang sedang berjalan. Selain itu, karena solusi analitik tidak bisa dikembangkan, sebab sistem sangat kompleks[9].

Salah satu permasalahan untuk menyelesaikan suatu analisis simulasi adalah dalam menentukan apakah suatu model simulasi sesuai dengan sistem nyata dan keakuratan dari simulasi yang dibuat. Verifikasi mempunyai kaitan dengan penentuan model simulasi konseptual (model asumsi) dan diterjemahkan kedalam suatu program komputer. Validasi merupakan proses dari menentukan apakah simulasi yang di buat dapat menjadi sistem yang akurat dan mendekati sistem nyata.

Model simulasi dapat diklasifikan menjadi beberapa jenis yaitu:

1. Model simulasi statis dan dinamis

Model simulasi statis merupakan model yang merupakan gambaran dari sebuah sistem pada titik waktu tertentu atau model simulasi dimana tidak ada peran variabel waktu di dalamnya.Di sisilain, model simulasi dinamis merupakan model simulasi yang menggambarkan sistem yang berkembang seiring berjalannya waktu.

2. Model simulasi deterministik dan stokastik

Model simulasi deterministik adalah sebuah model simulasi yang tidak melibatkan kejadian-kejadian acak di dalamnya sedangkan model stokastik adalah model simulasi yang melibatkan kejadian-kejadian acak didalamnya.

3. Model simulasi kontinu dan diskrit

Model simulasi kontinu merupakan sebuah model simulasi dimana perubahan status sistem terjadi terus menerus sepanjang waktu sedangkan model simulasi diskrit adalah sebuah model simulasi dengan perubahan status sistem yang terjadi hanya pada titik-titik waktu tertentu saja.

\subsection{Langkah-langkah Simulasi Monte Core}

Adapun langkah-langkah simulasi monte carlo adalah sebagai berikut[10]:

1. Membuat distribusi kemungkinan untuk variable penting. Terlebih dahulu dibuat Imperical Data distribusinya, yaitu: fungsi Probobilitas Distribusi Frekuensi,

$P D F=\frac{\text { F }}{\mathrm{I}}$

Dimana

PDF $=$ Probobilitas Distribusi Frekuensi

$\mathrm{F}=$ Frekuensi

$\mathrm{J}=$ Jumlah

2 Membangun distribusi kemungkinan kumulatif untuk tiap-tiap variable di tahap pertama.

Pada distribusi kedatangan pelanggan dapat ditentukan distribusi kemungkinan dan distribusi kumulatif.

$P D F=\frac{\text { F }}{\mathbb{I}}$

Dimana

PDF : Probobilitas Distribusi Frekuensi

$\mathrm{F}$ : Frekuensi

$\mathrm{J}:$ Jumlah

3. Menentukan grafik dan interval angka random untuk setiap kemungkinan.

Setelah menentukan porbabilitas kumulatif untuk tiap variable yang termasuk dalam simulasi, tentukan grafik setiap kedatangan pelanggan. Lalu beri batasan menentukan batas angka yang mewakili tiap kemungkinan. Hal tersebut ditujukan pada interval, penentuan interval didasari oleh kemungkinan kumulatif.

4. Membuat angka random.

Penarikan random number dilakukan dengan rumus LCM. Penarikan angka random untuk simulasi ini adalah sebagai berikut.

$\mathrm{Xi}+1=(\mathrm{a} . \mathrm{X} 1+\mathrm{c})$ Mod M........(2)

Dengan Syarat a, c < M, X $0>0$

Dimana

$\mathrm{Xi}$ : bilangan awal yang ditentukan

a : Konstanta perkalian

c : Konstanta penambahan

Mod : Modulus

M : Batasan nilai bilangan acak

5. Membuat simulasi dari rangkaian percobaan. 
Membuat simulasi dan rangkaian percobaan dari hasil pengambilan random number kemudian dapat disusun suatu tabel dari urutan hari-hari layanan servis. Untuk menentukan tabel hasil dapat disesuaikan pada tabel interval.

\section{HASIL DAN PEMBAHASAN}

Dalam analisis sistem bertujuan untuk melakukan identifikasi dan membahas mengenai rancangan pembuatan sistem yang diterapkan sesuai dengan latar belakang yang telah disampaikan dalam latar belakang sebelumnya, simulasi sistem antrian service sepeda motor pada bengkel resmi Honda. Dalam persoalan-persoalan yang akan muncul dalam pembuatan sistem, hal ini dilakukan agar pada proses perancangana sistem tidak terjadi kesalahan yang berarti, sehingga sistem yang dirancang dapat berjalan dengan baik, tepat guna dan ketahanan dari sistem tersebut akan lebih terjaga serta selesai tepat pada waktu yang telah ditentukan[11].

Dalam membangun sebuah simulasi sistem antrian dalam hal ini perlu diperhatikan adalah identifikasi masalah yang dihadapi dan analisis kebutuhan sistem dari identifikasi masalah dapat dijabarkan mengapa sistem tersebut perlu dikembangkan dan pada tahap analisis kebutuhan dapat pula diketahui hal-hal yang penting untuk diketahui atau diperlukan dalam membuat sistem ini.

Agar dapat lebih memahami mengenai proses yang dilakukan, simaklah sebuah contoh sederhana yang dapat dikerjakan seperti berikut:

1. Membuat distribusi kemungkinan untuk variable penting.

Dalam hal ini peneliti menghitung perkiraan kedatangan pelanggan menurut pola distribusi sebagai berikut:

Tabel 1. Distribusi kedatangan pelanggan

\begin{tabular}{|c|c|c|}
\hline No & $\begin{array}{c}\text { Pelayanan servis } \\
\text { (Hari) }\end{array}$ & Frekuensi kedatangan \\
\hline 1 & 1 & 45 \\
\hline 2 & 2 & 30 \\
\hline 3 & 3 & 35 \\
\hline 4 & 4 & 25 \\
\hline 5 & 5 & 32 \\
\hline 6 & 6 & 40 \\
\hline & Jumlah & 207 \\
\hline
\end{tabular}

2. Membangun distribusi kemungkinan kumulatif untuk tiap-tiap variable di tahap pertama.
Tabel 2. Distribusi kemungkinan dan distribusi kumulatif

\begin{tabular}{|c|c|c|c|}
\hline No & Frekuensi & $\begin{array}{c}\text { Distribusi } \\
\text { kemungkinan }\end{array}$ & $\begin{array}{c}\text { Distribusi } \\
\text { kumulatif }\end{array}$ \\
\hline 1 & 45 & $45 / 207=0.21$ & 0.21 \\
\hline 2 & 30 & $30 / 207=0.14$ & 0.35 \\
\hline 3 & 35 & $35 / 207=0.16$ & 0.51 \\
\hline 4 & 25 & $25 / 207=0.12$ & 0.63 \\
\hline 5 & 32 & $32 / 207=0.15$ & 0.78 \\
\hline 6 & 40 & $40 / 207=0.19$ & 0.97 \\
\hline
\end{tabular}

3. Menentukan grafik dan interval angka random untuk setiap kemungkinan.

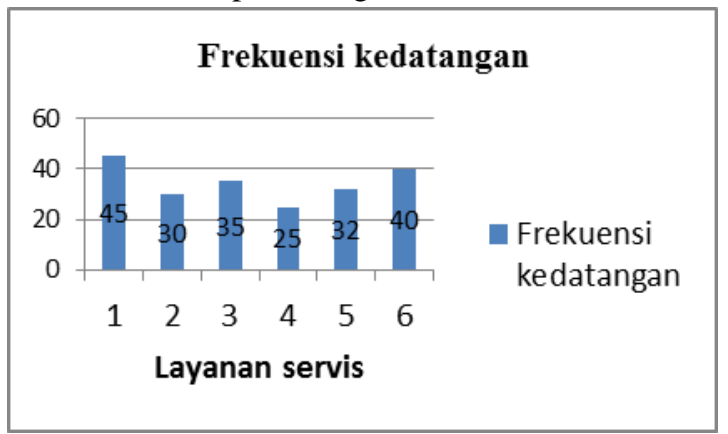

\section{Gambar 6. Grafik frekuensi kedatangan pelanggan}

Adapun interval atau batasan dari tiap kemungkinan adalah sebagai berikut:

Tabel 3. Interval atau batasan

\begin{tabular}{|c|c|c|c|c|c|}
\hline $\begin{array}{l}\mathrm{N} \\
\mathrm{O}\end{array}$ & $\begin{array}{l}\text { Kedat } \\
\text { angan } \\
\text { (hari) }\end{array}$ & $\begin{array}{l}\text { Frek } \\
\text { uensi }\end{array}$ & $\begin{array}{l}\text { Distrib } \\
\text { usi } \\
\text { kemun } \\
\text { gkinan }\end{array}$ & $\begin{array}{l}\text { Distribu } \\
\text { si } \\
\text { kumulat } \\
\text { if }\end{array}$ & $\begin{array}{c}\text { Inter } \\
\text { val }\end{array}$ \\
\hline 1 & 1 & 45 & $\begin{array}{c}45 / 207 \\
=0.21\end{array}$ & $\begin{array}{c}0+0.21= \\
0.21\end{array}$ & $0-21$ \\
\hline 2 & 2 & 30 & $\begin{array}{c}30 / 207 \\
=0.14\end{array}$ & $\begin{array}{l}0.21+0 . \\
14=0.35\end{array}$ & $\begin{array}{c}22- \\
35\end{array}$ \\
\hline 3 & 3 & 35 & $\begin{array}{c}35 / 207 \\
=0.16\end{array}$ & $\begin{array}{l}0.35+0 \\
16=0.51\end{array}$ & $\begin{array}{l}36- \\
51\end{array}$ \\
\hline 4 & 4 & 25 & $\begin{array}{c}25 / 207 \\
=0.12\end{array}$ & $\begin{array}{l}0.51+0 . \\
12=0.63\end{array}$ & $\begin{array}{l}52- \\
63\end{array}$ \\
\hline 5 & 5 & 32 & $\begin{array}{c}32 / 207 \\
=0.15\end{array}$ & $\begin{array}{l}0.63+0 \\
15=0.78\end{array}$ & $\begin{array}{l}64- \\
78\end{array}$ \\
\hline 6 & 6 & 40 & $\begin{array}{c}40 / 207 \\
=0.19\end{array}$ & $\begin{array}{l}0.78+0 . \\
19=0.97\end{array}$ & $\begin{array}{l}79- \\
97\end{array}$ \\
\hline
\end{tabular}


4. Membuat angka random.

Penarikan random number dilakukan dengan rumus LCM. Penarikan angka random untuk simulasi ini adalah sebagai berikut.

$$
\begin{aligned}
\mathrm{a}=12 \mathrm{X} 0 & =3 \mathrm{c}=23 \mathrm{~m}=100 \\
\mathrm{X} 1 & =(12.3+23) \bmod 100 \\
& =59 \bmod 100 \\
& =59 \\
\mathrm{X} 2 \quad & =(12.59+23) \bmod 100 \\
& =731 \bmod 100 \\
& =31 \\
\mathrm{X} 3 & =(12.31+23) \bmod 100 \\
& =395 \bmod 100 \\
& =95 \\
\mathrm{X} 4 & =(12.95+23) \bmod 100 \\
& =1163 \bmod 100 \\
& =63 \\
& =(12.63+23) \bmod 100 \\
\mathrm{X} 5 & =779 \bmod 100 \\
& =79 \\
& =(12.79+23) \bmod 100 \\
\mathrm{X} 6 & =971 \bmod 100 \\
& =71
\end{aligned}
$$

5. Membuat simulasi dari rangkaian percobaan.

\section{Tabel 4. Tabel Percobaan}

\begin{tabular}{|c|c|c|}
\hline No & Bilangan acak & Hasil \\
\hline 1 & 59 & 25 \\
\hline 2 & 31 & 30 \\
\hline 3 & 95 & 40 \\
\hline 4 & 63 & 25 \\
\hline 5 & 79 & 32 \\
\hline 6 & 71 & 192 \\
\hline
\end{tabular}

Jadi kemungkinan kedatangan pelanggan dalam 1 hari yang akan datang adalah 32 pelanggan, karena $192 / 6=32$

\section{Diagram Use Case}

Berikut adalah use case diagram untuk memodelkan aplikasi simulasi monte carlo pada bengkel resmi honda Medan.

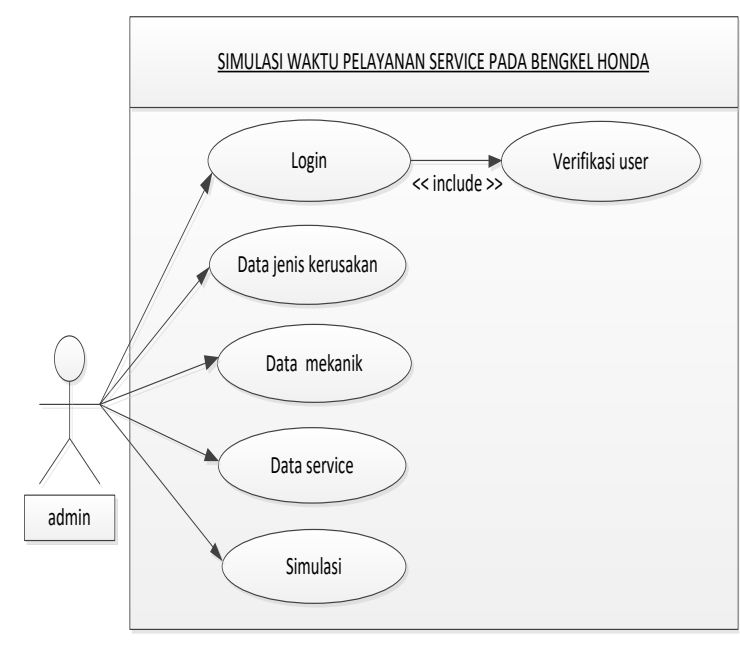

Gambar 7. Use Case Diagram

Skenario use case aplikasi simulasi sistem antrian service sepeda motor pada adalah sebagai berikut:

1. Aktor (admin) yang terlibat dalam sistem adalah bagian admin sebagai pengolah data.

2. Aplikasi simulasi sistem antrian ini dapat digunakan jika pengguna login kedalam sistem terlebih dahulu.

3. Pengguna yang valid akan dapat memasuki sistem, sementara yang tidak valid akan menerima pesan kesalahan.

4. Proses pengolahan data-data yang dibutuhkan dilakukan oleh operator(admin).

5. Proses pelaksanaan simulasi dilakukan oleh operator(admin).

\section{Diagram Kelas}

Diagram ini digunakan untuk mengorganisir objek-objek dari pemodelan Use Case dan mendokumentasikan hubungan diantara objek-objek tersebut.

Untuk menggambarkan hubungan dari entitas yang terdapat pada aplikasi simulasi pelayanan service ini, maka dapat menggunakan class diagram seperti terlihat pada gambar berikut: 


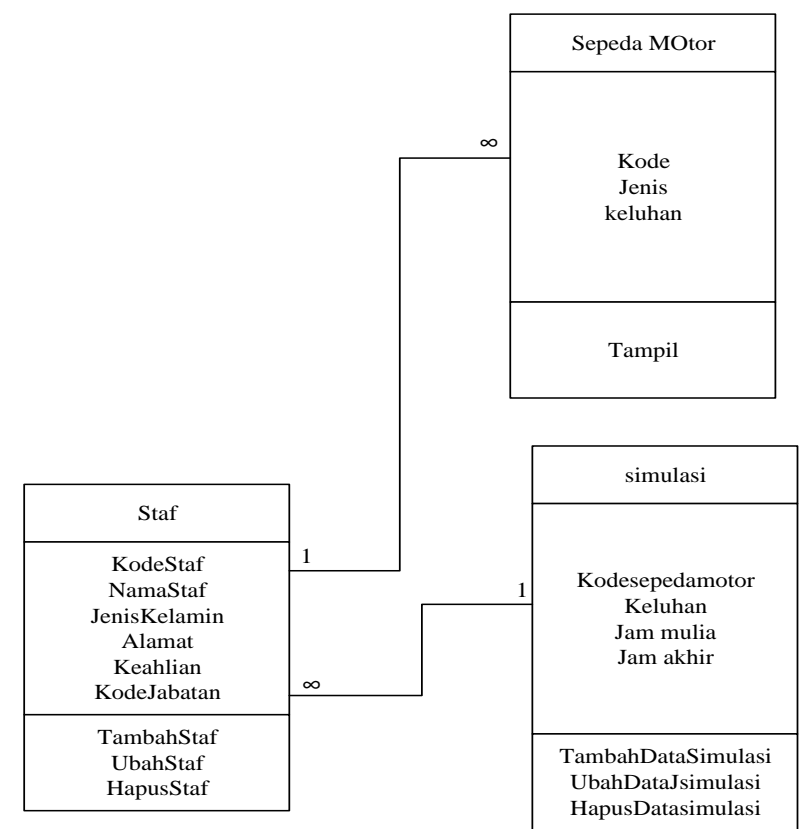

Gambar 7. Rancangan Class Diagram

\section{Perancangan Menu}

Perangkat lunak pengambilan keputusan dalam penjadwalan dengan algoritma monte carlo ini memiliki beberapa buah menu yaitu:

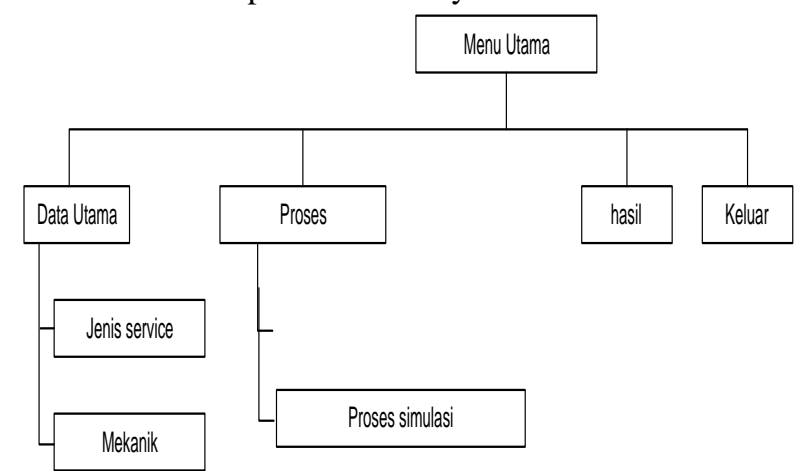

Gambar 8. Rancangan Menu Perangkat Lunak

Dengan penjelassan sebagai berkut:

1. Menu 'Variabel', yang berfungsi untuk melakukan pengaturan jumlah variabel, nama variabel dan daftar nama yang terdapat dalam variabel serta hubungan antara variabel tersebut. Meu ini memiliki beberapa sub menu, antara lain:

2. Menu 'Proses', yang berfungsi untuk menampilkan proses kerja dari algoritma monte carlo dan hasil simulasi yang diperoleh dengan menggunakan bantuan algoritma tersebut.

3. Menu 'Mengenai', yang berfungsi untuk menampilkan data-data pribadi dari pembuat perangkat lunak.
4. Menu 'Keluar', yang berfungsi untuk menutup perangkat lunak dan kembali ke sistem operasi Windows.

\section{Tampilan Hasil}

\section{Tampilan Link Simulasi}

Dapat dilihat pada gambar 9 tampilan link simulasi terdapat beberapa gambar server. Server tersebut yang digunakan sebagai tempat pelaksanaan service sepeda motor. Masing- masing server terdapat rincian jenis kerusakan yang dikerjakan, nomor plat kendaraan dan nama pemilik.

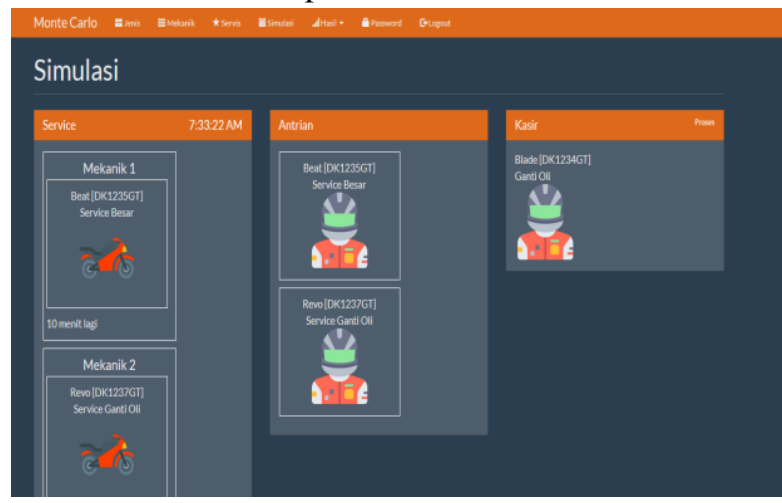

Gambar 9. Tampilan Link Simulasi

2. Tampilan Link Laporan (Rekap) untuk Simulasi

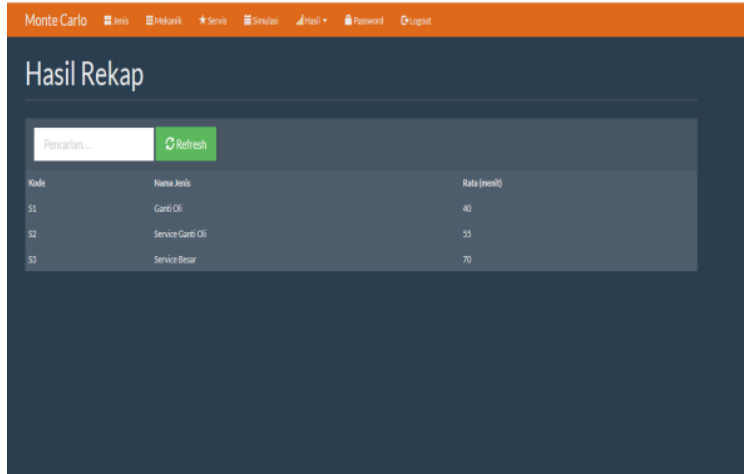

Gambar 10. Tampilan Link Laporan (Rekap)

3 Tampilan Link Laporan (Detail) untuk Simulasi

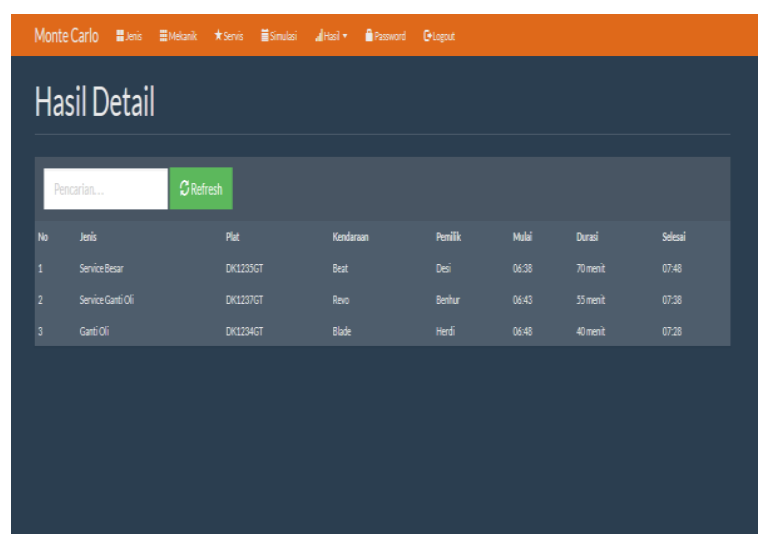

Gambar 11. Tampilan Link Laporan (Detail) untuk Simulasi 
Setelah link Simulasi dibahas, maka yang akan dibahas selanjutnya adalah link Laporan. Yang berguna untuk menampilkan hasil eksekusi laporan dari simulasi tersebut. Tampilan link Laporan untuk Simulasi dapat dilihat pada gambar 10 dan 11.

Pada form ini yang pertama terdapat waktu simulasi dan lama simulasi. Waktu simulasi merupakan waktu untuk memulai simulasi, sementara lama simulasi merupakan jangka waktu proses simulasi yang telah dilakukan. Dalam laporan terdapat rincian-rincian data yang telah di proses dalam link simulasi sebelumnya. Pada laporan ini akan terlihat secara otomatis berapa lama waktu datang, lama tunggu, dan waktu selesai dari customer dilayani oleh server.

Pada form ini terdapat 2 bentuk laporan simulasi yaitu Rekap dan Detail. Pada menu Rekap laporan yang dihasilkan ialah data jenis kerusakan dan rata-rata waktu pengerjaannya. Pada menu Detail laporan yang dihasilkan ialah data jenis kerusakan, plat nomor kendaraan, jenis kendaraan, nama pemilik, waktu mulai, lama waktu pengerjaan, dan waktu selesai di servis.

\section{PENUTUP}

\section{Kesimpulan}

Pada penelitian ini berhasil melakukan simulasi menggunakan metode monte carlo berdasarkan permasalahan yang ada pada CV. Kencana Sakti Motor. Berdasarkan hasil penelitian, terdapat perbedaan yang signifikan sebelum dan sesudah menggunakan sistem.

\section{Saran}

Berdasarkan hasil yang telah di uji pada sistem ini belum bisa menajadi acuan dalam penanganan pelayanan konsumen pada service Honda. Maka karena itulah penulis mengharapakan agar menggunakan metode simulasi yang lain agar hasil simulasi yang di hasilakan dapat memberikan hasil yang efektif dan efisien.

\section{DAFTAR PUSTAKA}

[1] Ratnasari and Rahadia. 2018. Pemodelandan Simulasi Sistem Antrian Pelayanan Konsumen Gerai MCD Solo Grand Mall dengan Arena. Seminar dan Konferensi Nasional IDEC.

[2] Cipta. 2018. Simulasi Antrian Pelayanan Pasien. Jurnal Matematika Dan Terapan. 1 (1).
[3] Andree et al. 2016 . Usulan Perbaikan Sistem Pelayanan Di Gerbang Tol Pasteur Berdasarkan Model Simulasi .Spektrum Industri.14(2) .

[4] Sentia et al. 2016 . Pendekatan Simulasi Untuk Analisis Antrian Pada Bengkel Servis Pt. X. Jurnal Optimasi Sistem Industri.15(2).

[5] Praba Martha et al. 2012. Analisis Sistem Antrian Pada Loket Pembayaran Pt.Pln. Research Gate.

[6] Antonius purba and Insan taufik. 2018 . Penerapan Sistem Antrian Registrasi Dengan Metode Multi Channel-Multi Phase. Jurnal Penelitian Teknik Informatika.1(2).

[7] Prihati . 2012 . Simulasi Dan Permodelan Sistem Antrian Pelanggan di loket pembayaran Rekening . Majalah Ilmiah Informatika.3(3).

[8] Purnawan and Hendikawati. 2013. Analisis model antrian perbaikan sepeda motor dengan menggunakan program visual basic. Unnes journal of mathematics. 2(1).

[9] Fadlilah and Rahmawati . 2017.Sistem Antrian Pada Pelayanan Customer Service PT.BANK X. Jurnal Gaussian. 6(1).

[10] Nurjaman et al. 2012.Simulasi Monte Carlo untuk pelayanan perpanjangan surat tanda nomor kendaraan bermotor. Jurnal STT. 9(1).

[11] Anthara. Analisis Sistem Antrian Gerbang Tol Pasteur Bandung Di Pt Jasa Marga (Persero)Tbk .Majalah Ilmiah UNIKOM. 12(1). 